\title{
Docking of Velpatasvir to the SARS-CoV-2 Viral Spike Protein-Human ACE2 Complex: repurposing for COVID-19
}

\section{Asad Zia}

Khyber Medical University

\section{Sohail Akhtar}

Khyber Medical University

Mubarak Ali Khan ( $\square$ makhan@awkum.edu.pk)

Abdul Wali Khan University https://orcid.org/0000-0002-7994-4244

\section{Research Article}

Keywords: Docking, Velpatasvir, SARS-CoV-2, Viral Spike, ACE2, repurposing

Posted Date: October 26th, 2021

DOI: https://doi.org/10.21203/rs.3.rs-1013200/v1

License: (1) (i) This work is licensed under a Creative Commons Attribution 4.0 International License.

Read Full License 


\section{Abstract}

The SARS-CoV-2 outbreak has challenged the world health community and is still out of control. Since there is no clinical drug available for the corona virus therefore the most important and the fastest way of medicines development is to find potential molecules from the marketed drugs. Herein, bioinformatics analysis on the spike protein (S) of CoV and human angiotensin receptor 2 (ACE-2) with already approved anti-HCV approved drug velpatasvir have been reported. We conducted molecular docking to determine the mode of interaction of velpatasvir and RNA dependent RNA polymerase enzyme as well as inhibition of attachment of S-protein with human host receptor ACE-2. We found that, velpatasvir not only binds tightly with S-protein-ACE2 interface but also with 2019-Cov RdRp, can alter the structure and function of the said proteins and hence will results in the eradication of viral infection. The findings of this study further support the idea of drug repurposing and will help to classify the most successful drugs against COVID-19.

\section{Introduction}

The coronavirus disease-2019 (COVID-19) that was appeared as an outbreak in China in December 2019 (Hui et al., 2020) is swiftly spreading and has affected more than 200 countries with a total of 4,628,903 cases and 312,009 deaths. as an interactive web-based dashboard of WHO to track COVID-19 in real-time as on May 19,20200n January 30,2020, it was declared as a public health concern on international basis by the World Health Organization (WHO) (Zhu et al., 2020, Chen et al., 2020c). Since the diseases is spreading very fast, and there are no specific vaccines or drugs available to combat the disease and the development of new drugs or vaccine takes years to be finally approved by the Food and drug regulatory authority (FDA); therefore, there is an urgent need to screen the available drugs using insilico methods to find out the suitable therapy for the treatment of COVID-19. Due to shortage of time, by repurposing the already available FDA approved antiviral drug using various ligand binding and the computational method with spike proteins of COVID -19 and the human Angiotensin Converting Enzyme 2 (ACE2) protein can be the best strategy to find out a suitable drug target. The angiotensin converting enzyme 2 (ACE2) has been identified as a receptor for the severe acute respiratory syndrome associated with coronavirus (SARS-CoV). Recent reports demonstrate that the spike protein (S) of SARS-CoV is sufficient to drive infection of cells and hence can be recognized by neutralizing antibodies in SARS patients (Wang Z et al., 2020, de Wit et al., 2020). Because of its essential role in viral entry, SARS-CoV S is an attractive target for vaccines and antiviral compounds. Coronavirus infection of target cells depends on interactions of $S$ with cellular receptors and the angiotensin converting enzyme 2 (ACE2) as a receptor for SARS-CoV. ACE2 expression on non-permissive cells (Hofmann and Pöhlmann, 2004) confers susceptibility to SARS-CoV infection (de Wit et al., 2020), indicating ACE2 as sufficient to allow viral entry (Kai and Kai, 2020).

SARS-CoV-2 is an enveloped positive-sense single-stranded RNA virus (ssRNA) consisting of 29,903 nucleotides and two untranslated sequences of 254 and 229 nucleotides at the 5 '- and 3 '-ends, respectively (GenBank No. MN908947). Comparable to SARS-CoV, the novel SARS-CoV-2 enters human 
cells via binding of the viral spike protein to the human angiotensin converting enzyme 2 (ACE2) (Zhang et al., 2020, Chen et al., 2020b, Bosch et al., 2003, Boopathi et al., 2020). In order to infect a host cell, the spikes of the virus must bind to a molecule on the cell surface. The novel coronavirus appears to use the same receptor as SARS-coronavirus for entry to human cells, and that receptor is the angiotensinconverting enzyme 2, ACE2 (Liu et al., 2020, Kai and Kai, 2020). In order to generate the daughter RNA genome, the coronavirus expresses an RNA-dependent RNA polymerase (RdRp), which is a crucial replicase that catalyzes the synthesis of a complementary RNA strand using the virus RNA template. This key enzyme of the coronaviral replication/transcription complex lays a solid foundation for the design of new antiviral therapeutics targeting RdRp of SARS-CoV-2 (Gao et al., 2020).

The concept of drug repurposing (or repositioning) came into the spotlight for several reasons. As it became apparent that drugs approved for one disease, may also exert activity for other indications, FDAapproved drugs became attractive as source for new drug development. A considerable advantage of old drugs in terms of time and costs for drug development is that their toxicity profile and pharmacokinetics are well-known in human beings. As the number of FDA approved drugs is continuously decreasing during the past three decades, drug repurposing may speed up the marketing of new drugs.

Some preliminary experiences with individual healing trials or animal experiments using anti-retroviral drugs (e.g. remdesivir, lopinavir, ritonavir, oseltamivir) and also alternative approaches from traditional Chinese medicine have been reported (Wang et al., 2020, Arabi et al., 2020, Lim et al., 2020, Omar et al., 2020). The repurposing of the already available FDA approved antiviral drug against coronavirus is a promising strategies for designing and development of novel drugs. Similarly, Velpatasvir is a DirectActing Antiviral (DAA) medication used as a part of combination therapy to treat chronic Hepatitis $C$, an infectious liver disease caused by infection with Hepatitis $C$ Virus (HCV). Velpatasvir acts as a defective substrate for NS5A (Non-Structural Protein 5A), a non-enzymatic viral protein that plays a key role in Hepatitis $C$ Virus replication, assembly, and modulation of host immune responses (Mogalian et al., 2017). It is also currently the most potent HCV antiviral medication in the market with a sustained virologic response (SVR) after 12 weeks of therapy of 93-99\% depending on genotype and level of cirrhosis and a high barrier to resistance (Zoulim et al., 2015).

The main aim of the present study is to identify the candidate drugs using molecular docking techniques. For this purpose, we used Velpatasvir to investigate its potential for repurposing binding pattern with Sprotein, ACE2 interface as well as COVID-19 RNA dependent RNA polymerase as anti- SARS-CoV-2 drug.

\section{Methodology}

\section{Ligand Preparation:}

The main objective of the current study is to test velpatasvir's binding pattern with S-protein: ACE2 interface as well as COVID-19 RNA dependent RNA polymerase for treating COVID-19 infection. The two dimensional structure, available at PubChem (CID:67683363,

https://pubchem.ncbi.nlm.nih.gov/compound/Velpatasvir) (Figure 1) was retrieved. The file in sdf format 
was converted to pdb using open babel (O'Boyle et al., 2011). Further the structural geometry was optimized using UCSF Chimera 1.14 (Pettersen et al., 2004). 5

\section{Target Preparation}

Recently reported three dimensional structures of SARS-CoV-2 S-protein-ACE2 complex as well as 2019nCoV RNA-dependent RNA polymerase (PDB IDs: 6VW1, 6M71, respectively) (https://www.rcsb.org/structure/6VW1, https://www.rcsb.org/structure/6m71) were retrieved from RCSB PDB. Co-crystallized ligands as well as crystallographic water molecules were excluded from the 3D coordinate files of selected targets.

\section{Active Site Prediction}

CASTp, an online tool, was used to identify the binding pocket of recently reported 2019-nCoV RNAdependent RNA polymerase (Tian et al., 2018).

\section{Molecular Docking}

Docking study was carried out using optimized ligand and protein structures via Autodock/vina (Trott and Olson, 2010). Preparatory steps, namely, padqt files generation for the targets and ligand as well as grid box setting at the active site was accomplished by using GUI program of Auto Dock Tool (Morris et al., 2009). The grid size was set at $50 \times 50 \times 50$ xyz points with a grid spacing of $0.375 \AA$. pdbqt files name along with grid box properties were written into a configuration file and conf file. Both protein targets and ligand were treated as rigid entities during docking. The results $<1.0 \AA$ were clustered in positional RMSD, and characterized with the most favorable free energy of binding. For further study, the pose with the lowest binding affinity has been extracted and aligned with the pdb files of studies proteins. Using different visualization tools, VMD (Humphrey et al., 1996), LigPlot+ (Laskowski and Swindells, 2011) and Chimera (Pettersen et al., 2004) 653, both hydrogen bond and ionic interactions along with hydrophobic contacts were analyzed.

\section{Results}

\section{Active Site of RNA-dependent RNA polymerase}

Since no information about the active pocket of 2019-nCoV RdRp has been reported yet, the important interacting residues using CASTp were identified for current study. ASP164, VAL 166, GLU167, PHE 429, LYS430, GLU431, GLU436, LUE437, LYS438, HIS439, PHE440, PHE441, PHE442, ASP452, TYR455, TYR 456, ILE494, ASN496, ASN497, ASP499, LYS500, SER501, GLY503,ASN507, LYS511, THR540, GLN541, MET542, ASN543, LEU544, TYR546, ALA547, ILE548, SER549, ALA550, LYS551, ARG553, ALA554, ARG555, THR556, VAL557, ALA 558, GLY 559, THR 565, ASN 568, ARG 569, HIS572, GLN573, LEU576, LYS577, ALA580, VAL588, ILE589, GLY590, THR591, SER592, LYS593, PHE594, TRP598, MET601, LEU602, GLY616, TRP617, ASP618, TYR619, PR0620, LYS621, CYS622, ASP623, ARG624, GLU665, VAL667, LYS676, THR680, SER681, SER682, GLY683, ASP684, ALA685, THR686, THR687, ALA688, 
TYR689, ASN691, MET756, LEU758, SER759, ASP760, ASP761, ALA762, VAL763, VAL792, PHE793, SER795, ALA797, LYS798, CYS799, TRP800, HIS810, GLU811, PHE812, CYS813, SER814, GLN815, HIS816, ASP833, SER835, ARG836, ILE837, ALA840, GLY841, PHE843, VAL844, ASP845, ILE847, VAL848, LEU854, MET855, GLU857, ARG858, PHE859, SER861, LEU862, ILE864, ASN865

\section{Docking Studies}

In order to provide a deeper insight into the inhibitory potential of selected targets, molecular docking study using velpatasvir was carried out. Autoodock/Vina generated nine bound ligand conformations for each studied (Table 1), among these the best conformations with biding affinities of $-11.7 \mathrm{kcal} / \mathrm{mol}$ (ligand-interface) and $-12.4 \mathrm{kcal} / \mathrm{mol}$ (ligand-RdRp) were selected for further analysis.

GLU23, GLN24, ALA25, LYS26,THR27, Phe28, Leu29, Asp30, Lys31, Phe32, Asn33, His34, Glu35, Ala36, Glu37, Asp38, Leu39, Phe40, Tyr41, Gln42, Lys353 of ACE2 receptor present at interface and Lys403, Val417, Tyr421, Tyr449, Tyr453, Leu455, Phe456, Tyr489, Gln493, Ser494, Tyr495, Gly496, Phe497, GIn498, Asn501 and Tyr505 of S-protein receptor binding domain (RBD) were found to be the key interacting residues (Figure. 2) Vigilant exploration of selected best pose using VMD, revealed important ligand-RBD/hACE2 interface interactions. Hydrogen bond as well as ionic interactions with key residues of RBD/hACE2 interface (Glu31, Asp38, Lys 353, Leu455 and Asn501) observed are shown in Table 2, Figure. 3. In particular, Asp38 of hACE2 interacted in several ways-electrostatic complementarity, hydrogen bonding and hydrophobic interactions-with the electronegative as well as carbonyl groups of studied compound. This suggests that it might be an anchoring residue which plays a vital role in binding with the selected target. Further, analysis using LigPlot+ also highlighted the key residues involved in ligand-interface interactions (Figure. 4). Based on binding pattern observed, it was found that velpatasvir has more preference for residues belonging to the ACE2 receptor portion of the interface, hence we hypothesize that these favorable interactions may in-turn limit the binding of the SARS-CoV-2 S-protein with the ACE2 receptor and thus restricting the infection.

The top ranked docked pose of velpatasvir and newly emerged coronavirus RdRp was studied in detail to extract beneficial information for the better understanding of the binding mechanisms of ligand-RdRp. Velpatasvir bind deeply inside the predicted pocket of 2019-CoV RdRp (Figure. 5). Molecular interactions plotted using VMD revealed that Gly590 and ALA688 of RdRp interacted with carbonyl as well as electrostatic atoms groups of velpatasvir by means of hydrogen bond, electrostatic interactions and hydrophobic contacts. ASP623 and CYS622 also formed hydrogen bond as well as ionic interactions, hence playing an important role in stabilizing the binding of ligand with protein. Additionally, SER759 showed hydrophobic interaction with carbonyl atoms of ligand (Figure 6). Two dimensional interactions map was also generated using LigPlot+ also highlighted hydrophobic contacts (Figure 7).

Table 1: Bound ligand conformations for Velpatasvir with binding affinities. 


\begin{tabular}{|l|l|l|}
\hline Model & $\begin{array}{l}\text { Velpatasvir-RBD-hCAE2 } \\
\text { Affinity (kcal/mol) }\end{array}$ & $\begin{array}{l}\text { Velpatasvir-RdRp } \\
\text { Affinity (kcal/mol) }\end{array}$ \\
\hline 1 & -11.1 & 12.4 \\
\hline 2 & -9.7 & -12.2 \\
\hline 3 & -9.7 & -12.1 \\
\hline 4 & -9.7 & -11.6 \\
\hline 5 & -9.4 & -11.4 \\
\hline 6 & -9.4 & -11.4 \\
\hline 7 & -9.3 & -11.3 \\
\hline 8 & -9.3 & -11.2 \\
\hline 9 & -9.2 & -10.9 \\
\hline
\end{tabular}

Table.2 Important interactions of Velpatasvir with RBD/hACE2 and 2019-CoV RdRp interface interactions 


\begin{tabular}{|c|c|c|c|}
\hline Complex & $\begin{array}{l}\text { Hydrogen } \\
\text { Interactions }\end{array}$ & Ionic Interactions & Hydrophobic Contacts \\
\hline $\begin{array}{l}\text { Velpatasvir } \\
\text { RBD/hACE2 }\end{array}$ & 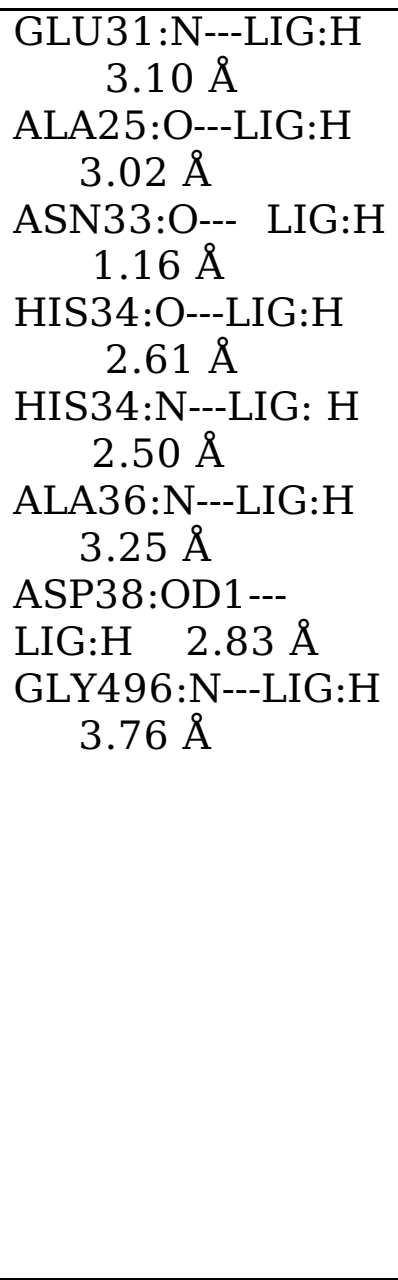 & $\begin{array}{l}\text { ASP38:OD1--- } \\
\text { LIG:N 3.59 } \\
\text { ASN501:ND2--- } \\
\text { LIG:O 3.81 } \AA\end{array}$ & $\begin{array}{l}\text { ASP38:CA---LIG:C } 1.60 \AA \\
\text { ASP38:CA---LIG:C } 2.30 \AA \\
\text { ASP38:CA---LIG:C } 2.10 \AA \\
\text { ASP38:CA---LIG:C } 3.89 \AA \\
\text { ASP38:CA---LIG:C } 2.51 \AA \\
\text { ASP38:CA---LIG:C } 3.91 \AA \\
\text { ASP38:CB---LIG:C } 2.00 \AA \\
\text { ASP38:CB---LIG:C } 3.40 \AA \\
\text { ASP38:C---LIG:C2.36 } \\
\text { ASP38:C---LIG:C } 2.91 \AA \\
\text { LYS31:CA---LIG:C } 2.60 \AA \\
\text { LYS31:CA---LIG:C } 2.59 \AA \\
\text { LYS31:CA---LIG:C } 1.94 \AA \\
\text { LYS31:CA---LIG:C } 1.98 \AA \\
\text { LYS31:CA---LIG:C } 2.83 \AA \\
\text { LYS31:CA---LIG:C } 3.32 \AA \\
\text { LYS31:CB---LIG:C } 3.31 \AA \\
\text { LYS31:CA---LIG:C } 3.06 \AA \\
\text { LYS31:CA---LIG:C } 3.33 \AA \\
\text { LYS31:CG---LIG:C } 3.63 \AA \\
\text { LYS:31CD---UNK:C } 3.197 \AA \\
\text { LYS353:CE---LIG:C } 2.99 \AA \\
\text { LYS353:CE---LIG:C } 1.97 \AA \\
\text { LYS353:CE---LIG:C } 3.24 \AA \\
\text { LEU455:CD1---LIG:C3.67 } \\
\text { LEU455:CD1---LIG:C } 3.47 \AA \\
\text { LEU455:CD2---LIG:C } 3.70 \AA\end{array}$ \\
\hline $\begin{array}{l}\text { Velpatasvir } \\
\text { RdRp }\end{array}$ & $\begin{array}{l}\text { GLY590:HN---LIG } \\
\text { O } 3.73 \AA \\
\text { ALA685:O---LIG: } \\
\text { H } 3.91 \AA \\
\text { ASP623:HN--- } \\
\text { LIG:O 2.61 } \\
\text { CYS622:HN--- } \\
\text { LIG:O 2.45 }\end{array}$ & $\begin{array}{l}\text { GLY590:N--- } \\
\text { LIG:O 3.92 } \\
\text { ALA684:O--- } \\
\text { LIG:N 3.76 } \\
\text { ASP623:N---LIG:O } \\
\text { 3.58 } \AA \\
\text { CYS622:N---LIG:O } \\
3.23 \AA\end{array}$ & $\begin{array}{l}\text { GLY590:CA---LIG:C } 3.99 \AA \\
\text { ALA688:CB---LIG: C } 3.74 \AA \\
\text { SER759:CB---LIG:C } 3.88 \AA \\
\text { SER759:CB---LIG:C } 3.62 \AA \\
\text { SER759:CB---LIG:C } 3.83 \AA\end{array}$ \\
\hline
\end{tabular}

\section{Discussion}

Potential anti-coronavirus therapies can be divided into two categories depending on the target, one is acting on the human immune system or human cells, and the other is on coronavirus itself. In terms of the human immune system, the innate immune system response plays an important role in controlling the replication and infection of coronavirus, and interferon is expected to enhance the immune response (Wu et al., 2020, Omrani et al., 2014). Blocking the signal pathways of human cells required for virus replication may show a certain antiviral effect. In addition, viruses often bind to receptor proteins on the surface of cells in order to enter the human cells, for example, the SARS virus binds to the angiotensin-converting enzyme 2 (ACE2) receptor (Tu et al., 2020, Ge et al., 2013). The design of enzyme 
inhibitors as therapeutic platforms against CoV requires the control of multiple pharmacologic features beyond the interaction and ACE-2- and furin-targeting drugs (Hasan et al., 2020, Baron et al., 2020, Kong et al., 2020).

There is a dire need of anti-SARS-cov2 drugs to overcome the recent SARS-cov2 pandemic. A number of drugs with experimental clinical knowledge has been recently checked for anti- SARS-cov2 and few of them are in practical use with some side effects. Recent articles on drug repurposing have narrow directed approaches against the single target; here we reported holistic approach of targeting both human ACE2-S protein complex and viral RdRp proteins against COVID-19 infection. As HCV and SARS-cov2 are single positive strand envelope viruses, share more or less similar mechanism of replication and translation in host cells. Velpatsvir is an inhibitor of the HCV Non-Structural Protein 5A (NS5A) (Mogalian et al., 2017). This protein is crucial for viral RNA replication and assembly of HCV. Hence, it is reasonable to speculate that these drugs may also exert activity against SARS-CoV-2. In our study we observed that the binding pattern of velpatasvir has more preference for residues belonging to the ACE2 receptor portion of the interface, and we hypothesize that these favorable interactions may in-turn limit the binding of the SARS-CoV-2 S-protein with the ACE2 receptor, thus restricting the infection. Binding of small molecule inhibitors to multiple targets at the same time may increase the therapeutic efficacy and decrease the probability of development of resistance to one of the targets (Efferth and Koch, 2011). Especially, natural products are known to bind to multiple targets. Interestingly, velpatasvir bound to RdRp, spike and ACE2 complex at the present in the silico study. The validity of our results is supported by previous screening of many antiviral drugs IDX-184 against Middle East Respiratory Syndrome (MERS) coronavirus (Elfiky et al., 2017), Danoprevir and velpatasvir against SARS-CoV 2 (Chen et al., 2020a). In addition to target the RNA dependent RNA polymerase, the velpatasvir displayed inhibitory effect for ACE2 and angiotensin. It is the first article that reported velpatasvir binds to the contact surface of ACE2 spike complex. Chen et al. (Chen et al., 2020d) described most of the compounds alternate ACE2 function rather than binding to ACE2-spike complex. Hesperidin is the only natural compound which alternates the interaction of spike and ACE2 complex (Wu et al., 2020). ACE-2 and TMPRSS2 are main entry points for SARS-CoV-2 into human cell and are limited by a protease inhibitor (Hoffmann et al., 2020).

\section{Conclusion}

The outbreak of SARS-CoV 2 has challenged the world health community to fight against it. There is no specific therapy available yet. Computational biologist and virologists are trying virtual screening based molecular docking methods to identify novel compounds and to investigate the efficacy of already approved drugs. In the present study, we screened the already FDA approved anti-HCV drug velpatasvir as promising candidate for the inhibition of spike protein $(S)$ attachment to human angiotensin receptor-2 (ACE-2) and the inhibition of RNA dependent RNA polymerase that is a crucial enzyme of virus replication. We found that velpatasvir not only binds tightly with S-protein-ACE2 interface but also with 2019-Cov RdRp, which may alter the structure and function of the said proteins and hence will result in 
the eradication of viral infection. Hence, these findings reported here could be a starting point to the repurposing of velpatasvir as a possible antiviral against SARS-CoV-2 infection.

\section{References}

ARABI, Y. M., FOWLER, R. \& HAYDEN, F. G. 2020. Critical care management of adults with communityacquired severe respiratory viral infection. Intensive care medicine, 46, 315-328.

BARON, S. A., DEVAUX, C., COLSON, P., RAOULT, D. \& ROLAIN, J.-M. 2020. Teicoplanin: an alternative drug for the treatment of coronavirus COVID-19. Int J Antimicrob Agents, 105944.

BOOPATHI, S., POMA, A. B. \& KOLANDAIVEL, P. 2020. Novel 2019 Coronavirus Structure, Mechanism of Action, Antiviral drug promises and rule out against its treatment. Journal of Biomolecular Structure and Dynamics, 1-14.

BOSCH, B. J., VAN DER ZEE, R., DE HAAN, C. A. \& ROTTIER, P. J. 2003. The coronavirus spike protein is a class I virus fusion protein: structural and functional characterization of the fusion core complex. Journal of virology, 77, 8801-8811.

CHEN, N., ZHOU, M., DONG, X., QU, J., GONG, F., HAN, Y., QIU, Y., WANG, J., LIU, Y. \& WEI, Y. 2020a. Epidemiological and clinical characteristics of 99 cases of 2019 novel coronavirus pneumonia in Wuhan, China: a descriptive study. The Lancet, 395, 507-513.

CHEN, Y., GUO, Y., PAN, Y. \& ZHAO, Z. J. 2020b. Structure analysis of the receptor binding of 2019-nCoV. Biochemical and biophysical research communications, 525, 135-140.

CHEN, Y., LIU, Q. \& GUO, D. 2020c. Emerging coronaviruses: genome structure, replication, and pathogenesis. Journal of medical virology, 92, 418-423.

CHEN, Y. W., YIU, C.-P. B. \& WONG, K.-Y. 2020d. Prediction of the SARS-CoV-2 (2019-nCoV) 3C-like protease (3CL pro) structure: virtual screening reveals velpatasvir, ledipasvir, and other drug repurposing candidates. F1000Research, 9.

DE WIT, E., FELDMANN, F., CRONIN, J., JORDAN, R., OKUMURA, A., THOMAS, T., SCOTT, D., CIHLAR, T. \& FELDMANN, H. 2020. Prophylactic and therapeutic remdesivir (GS-5734) treatment in the rhesus macaque model of MERS-CoV infection. Proceedings of the National Academy of Sciences, 117, 67716776.

EFFERTH, T. \& KOCH, E. 2011. Complex interactions between phytochemicals. The multi-target therapeutic concept of phytotherapy. Current drug targets, 12, 122-132.

ELFIKY, A. A., MAHDY, S. M. \& ELSHEMEY, W. M. 2017. Quantitative structure-activity relationship and molecular docking revealed a potency of anti-hepatitis $\mathrm{C}$ virus drugs against human corona viruses. Journal of medical virology, 89, 1040-1047. 
GAO, Y., YAN, L., HUANG, Y., LIU, F., ZHAO, Y., CAO, L., WANG, T., SUN, Q., MING, Z. \& ZHANG, L. 2020. Structure of RNA-dependent RNA polymerase from 2019-nCoV, a major antiviral drug target. BioRxiv.

GE, X.-Y., LI, J.-L., YANG, X.-L., CHMURA, A. A., ZHU, G., EPSTEIN, J. H., MAZET, J. K., HU, B., ZHANG, W. \& PENG, C. 2013. Isolation and characterization of a bat SARS-like coronavirus that uses the ACE2 receptor. Nature, 503, 535-538.

HASAN, A., PARAY, B. A., HUSSAIN, A., QADIR, F. A., ATTAR, F., AZIZ, F. M., SHARIFI, M., DERAKHSHANKHAH, H., RASTI, B. \& MEHRABI, M. 2020. A review on the cleavage priming of the spike protein on coronavirus by angiotensin-converting enzyme-2 and furin. Journal of Biomolecular Structure and Dynamics, 1-13.

HOFFMANN, M., KLEINE-WEBER, H., SCHROEDER, S., KRÜGER, N., HERRLER, T., ERICHSEN, S., SCHIERGENS, T. S., HERRLER, G., WU, N.-H. \& NITSCHE, A. 2020. SARS-CoV-2 cell entry depends on ACE2 and TMPRSS 2 and is blocked by a clinically proven protease inhibitor. Cell.

HOFMANN, H. \& PÖHLMANN, S. 2004. Cellular entry of the SARS coronavirus. Trends in microbiology, 12, 466-472.

HUI, D., AZHAR EI, MADANI TA, NTOUMI F, KOCK R, DAR O, IPPOLITO G, MCHUGH TD, MEMISH ZA, DROSTEN C, ZUMLA A \& E, P. 2020. The continuing 2019-nCoV epidemic threat of novel coronaviruses to global health-the latest 2019 novel coronavirus outbreak in Wuhan. China, 91, 264-266.

HUMPHREY, W., DALKE, A. \& SCHULTEN, K. 1996. VMD: Visual molecular dynamics. Journal of Molecular Graphics, 14, 33-38.

KAl, H. \& KAI, M. 2020. Interactions of coronaviruses with ACE2, angiotensin II, and RAS inhibitorslessons from available evidence and insights into COVID-19. Hypertension Research, 1-7.

KONG, R., YANG, G., XUE, R., LIU, M., WANG, F., HU, J., GUO, X. \& CHANG, S. 2020. COVID-19 Docking Server: An interactive server for docking small molecules, peptides and antibodies against potential targets of COVID-19. arXiv preprint arXiv:2003.00163.

LASKOWSKI, R. A. \& SWINDELLS, M. B. 2011. LigPlot+: multiple ligand-protein interaction diagrams for drug discovery. J Chem Inf Model, 51, 2778-86.

LIM, J., JEON, S., SHIN, H.-Y., KIM, M. J., SEONG, Y. M., LEE, W. J., CHOE, K.-W., KANG, Y. M., LEE, B. \& PARK, S.-J. 2020. Case of the index patient who caused tertiary transmission of COVID-19 infection in Korea: the application of lopinavir/ritonavir for the treatment of COVID-19 infected pneumonia monitored by quantitative RT-PCR. Journal of Korean medical science, 35.

LIU, Z., XIAO, X., WEI, X., LI, J., YANG, J., TAN, H., ZHU, J., ZHANG, Q., WU, J. \& LIU, L. 2020. Composition and divergence of coronavirus spike proteins and host ACE2 receptors predict potential intermediate hosts of SARS-CoV-2. Journal of medical virology, 92, 595-601. 
MOGALIAN, E., GERMAN, P., KEARNEY, B. P., YANG, C. Y., BRAINARD, D., LINK, J., MCNALLY, J., HAN, L., LING, J. \& MATHIAS, A. 2017. Preclinical pharmacokinetics and first-in-human pharmacokinetics, safety, and tolerability of velpatasvir, a pangenotypic hepatitis C virus NS5A inhibitor, in healthy subjects. Antimicrobial agents and chemotherapy, 61, e02084-16.

MORRIS, G. M., HUEY, R., LINDSTROM, W., SANNER, M. F., BELEW, R. K., GOODSELL, D. S. \& OLSON, A. J. 2009. AutoDock4 and AutoDockTools4: Automated docking with selective receptor flexibility. J Comput Chem, 30, 2785-91.

O'BOYLE, N. M., BANCK, M., JAMES, C. A., MORLEY, C., VANDERMEERSCH, T. \& HUTCHISON, G. R. 2011. Open Babel: An open chemical toolbox. Journal of Cheminformatics, 3, 33.

OMAR, S., BOUZIANE, I., BOUSLAMA, Z. \& DJEMEL, A. 2020. In-Silico Identification of Potent Inhibitors of COVID-19 Main Protease (Mpro) and Angiotensin Converting Enzyme 2 (ACE2) from Natural Products: Quercetin, Hispidulin, and Cirsimaritin Exhibited Better Potential Inhibition than Hydroxy-Chloroquine Against COVID-19 Main Protease Active Site and ACE2.

OMRANI, A. S., SAAD, M. M., BAIG, K., BAHLOUL, A., ABDUL-MATIN, M., ALAIDAROOS, A. Y., ALMAKHLAFI, G. A., ALBARRAK, M. M., MEMISH, Z. A. \& ALBARRAK, A. M. 2014. Ribavirin and interferon alfa-2a for severe Middle East respiratory syndrome coronavirus infection: a retrospective cohort study. The Lancet Infectious Diseases, 14, 1090-1095.

PETTERSEN, E. F., GODDARD, T. D., HUANG, C. C., COUCH, G. S., GREENBLATT, D. M., MENG, E. C. \& FERRIN, T. E. 2004. UCSF Chimera-a visualization system for exploratory research and analysis. Journal of computational chemistry, 25, 1605-1612.

TIAN, W., CHEN, C., LEI, X., ZHAO, J. \& LIANG, J. 2018. CASTp 3.0: computed atlas of surface topography of proteins. Nucleic Acids Res, 46, W363-w367.

TROTT, O. \& OLSON, A. J. 2010. AutoDock Vina: improving the speed and accuracy of docking with a new scoring function, efficient optimization, and multithreading. Journal of computational chemistry, 31, 455461.

TU, Y.-F., CHIEN, C.-S., YARMISHYN, A. A., LIN, Y.-Y., LUO, Y.-H., LIN, Y.-T., LAI, W.-Y., YANG, D.-M., CHOU, S.-J. \& YANG, Y.-P. 2020. A review of SARS-CoV-2 and the ongoing clinical trials. International journal of molecular sciences, $21,2657$.

WANG Z, CHEN X, LU Y, CHEN F \& W, Z. 2020. Clinical characteristics and therapeutic procedure for four cases with 2019 novel coronavirus pneumonia receiving combined Chinese and Western medicine treatment. Bioscience trends, 14 64-68.

WANG, Z., CHEN, X., LU, Y., CHEN, F. \& ZHANG, W. 2020. Clinical characteristics and therapeutic procedure for four cases with 2019 novel coronavirus pneumonia receiving combined Chinese and Western 
medicine treatment. Bioscience trends, 14, 64-68.

WU, C., LIU, Y., YANG, Y., ZHANG, P., ZHONG, W., WANG, Y., WANG, Q., XU, Y., LI, M. \& LI, X. 2020. Analysis of therapeutic targets for SARS-CoV-2 and discovery of potential drugs by computational methods. Acta Pharmaceutica Sinica B.

ZHANG, H., PENNINGER, J. M., LI, Y., ZHONG, N. \& SLUTSKY, A. S. 2020. Angiotensin-converting enzyme 2 (ACE2) as a SARS-CoV-2 receptor: molecular mechanisms and potential therapeutic target. Intensive care medicine, 1-5.

ZHU, N., ZHANG, D., WANG, W., LI, X., YANG, B., SONG, J., ZHAO, X., HUANG, B., SHI, W. \& LU, R. 2020. A novel coronavirus from patients with pneumonia in China, 2019. New England Journal of Medicine.

ZOULIM, F., LIANG, T. J., GERBES, A. L., AGHEMO, A., DEUFFIC-BURBAN, S., DUSHEIKO, G., FRIED, M. W., POL, S., ROCKSTROH, J. K. \& TERRAULT, N. A. 2015. Hepatitis C virus treatment in the real world: optimising treatment and access to therapies. Gut, 64, 1824-1833.

\section{Figures}

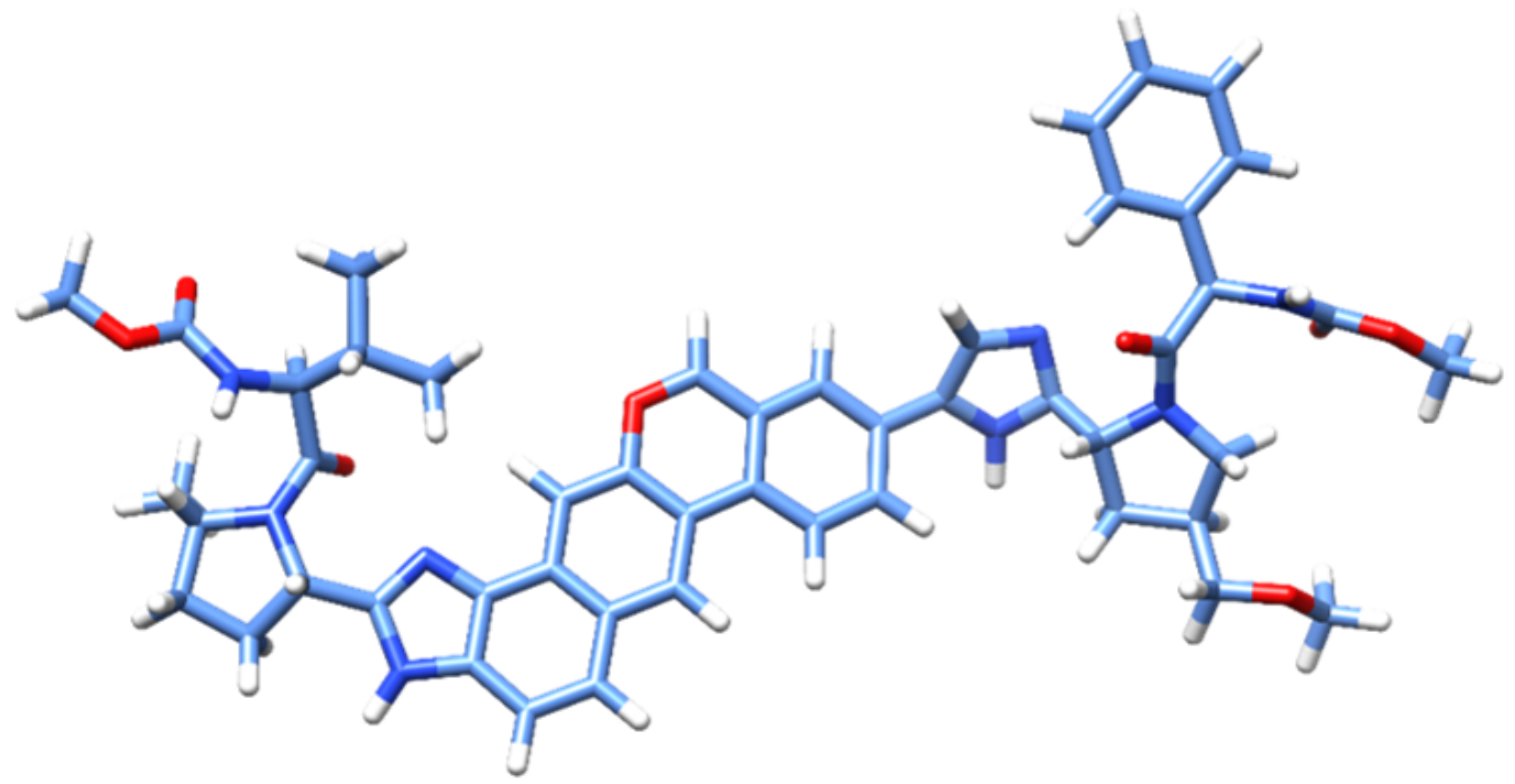

\section{Figure 1}

Optimized Structure of Velpatasvir 


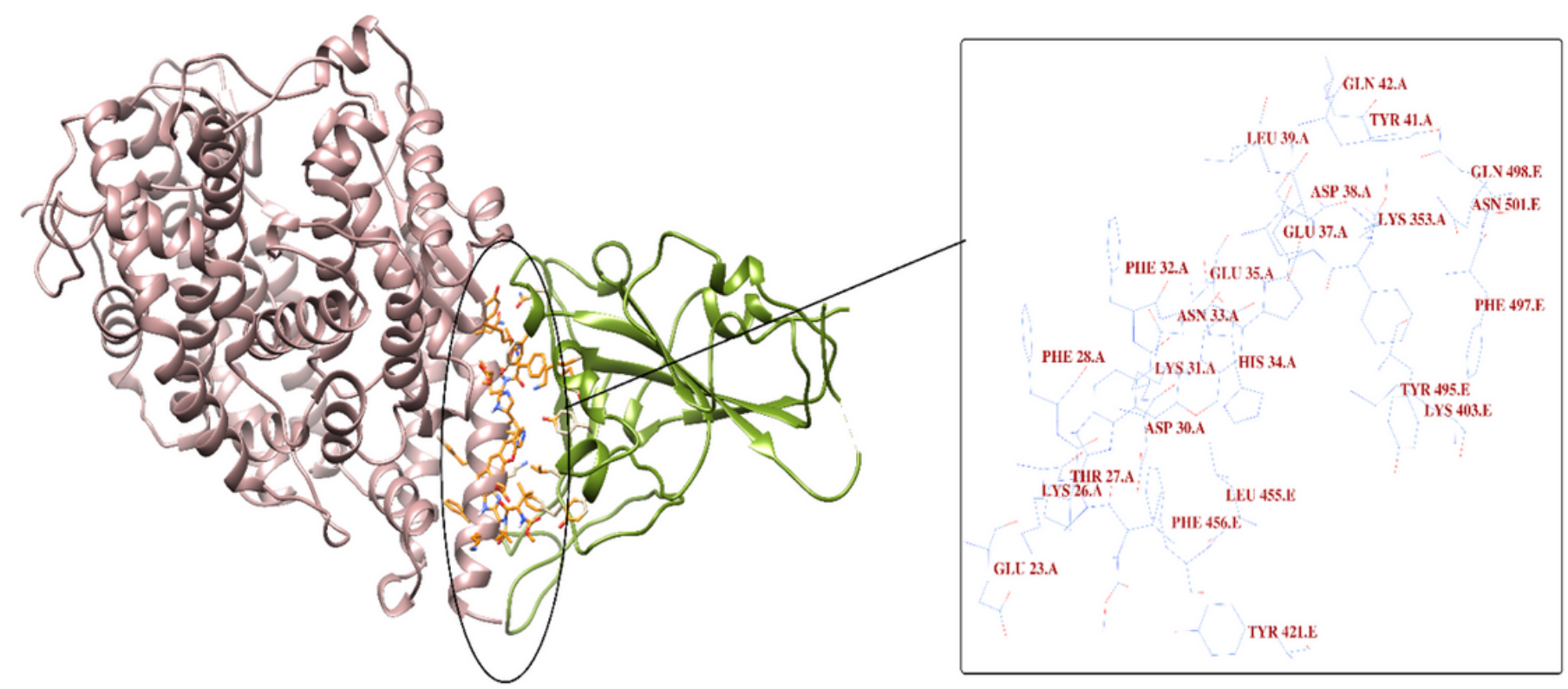

Figure 2

Top ranked pose: compound docked at the viral protein and ACE2 receptor interface. Receptor is in sandy brown color and spike protein is in green.

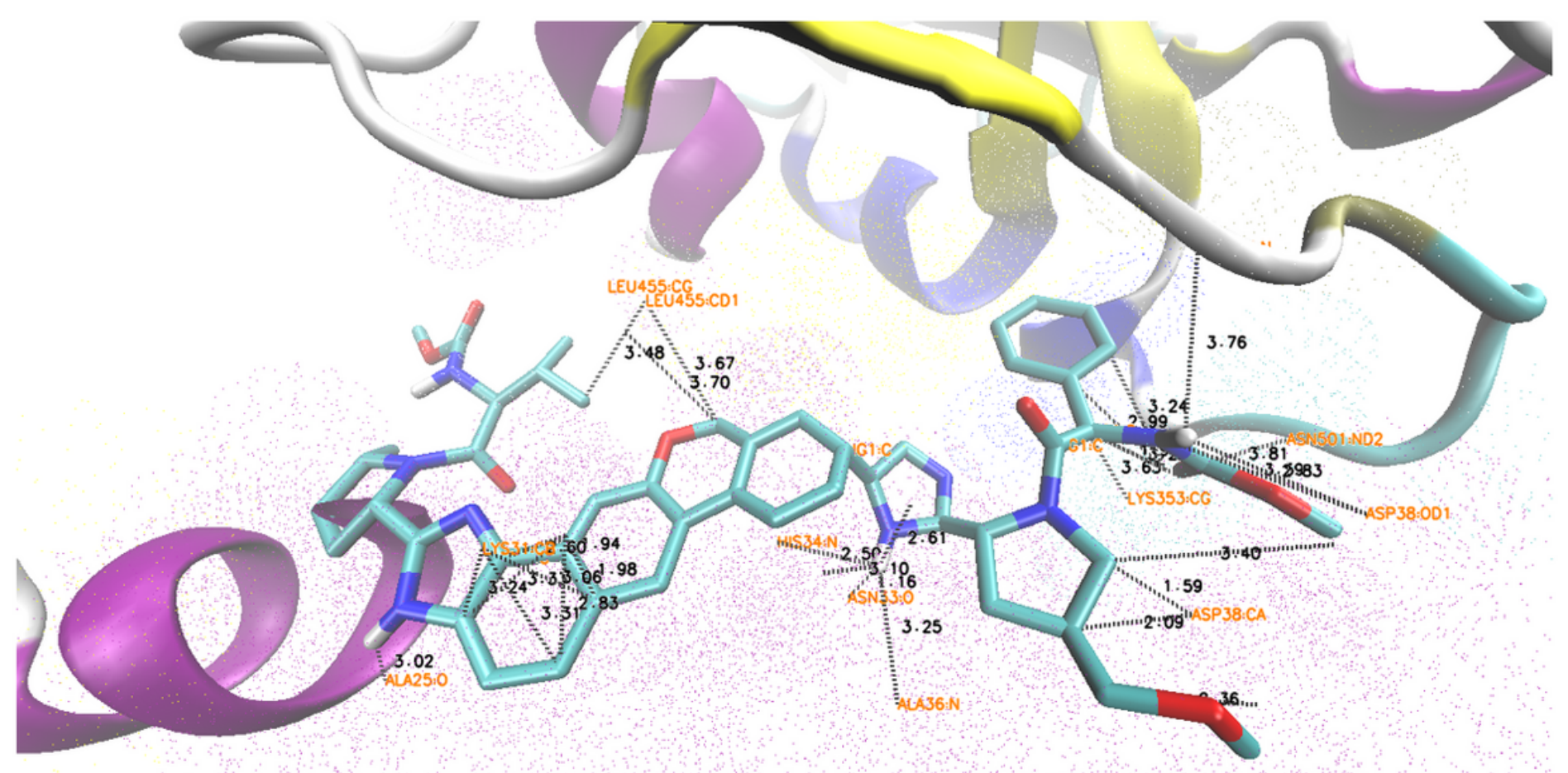

Figure 3 
Three-dimensional depiction of hydrogen bond and ionic interactions of key residues of RBD/hACE2 receptor interface and Velpatasvir using VMD.

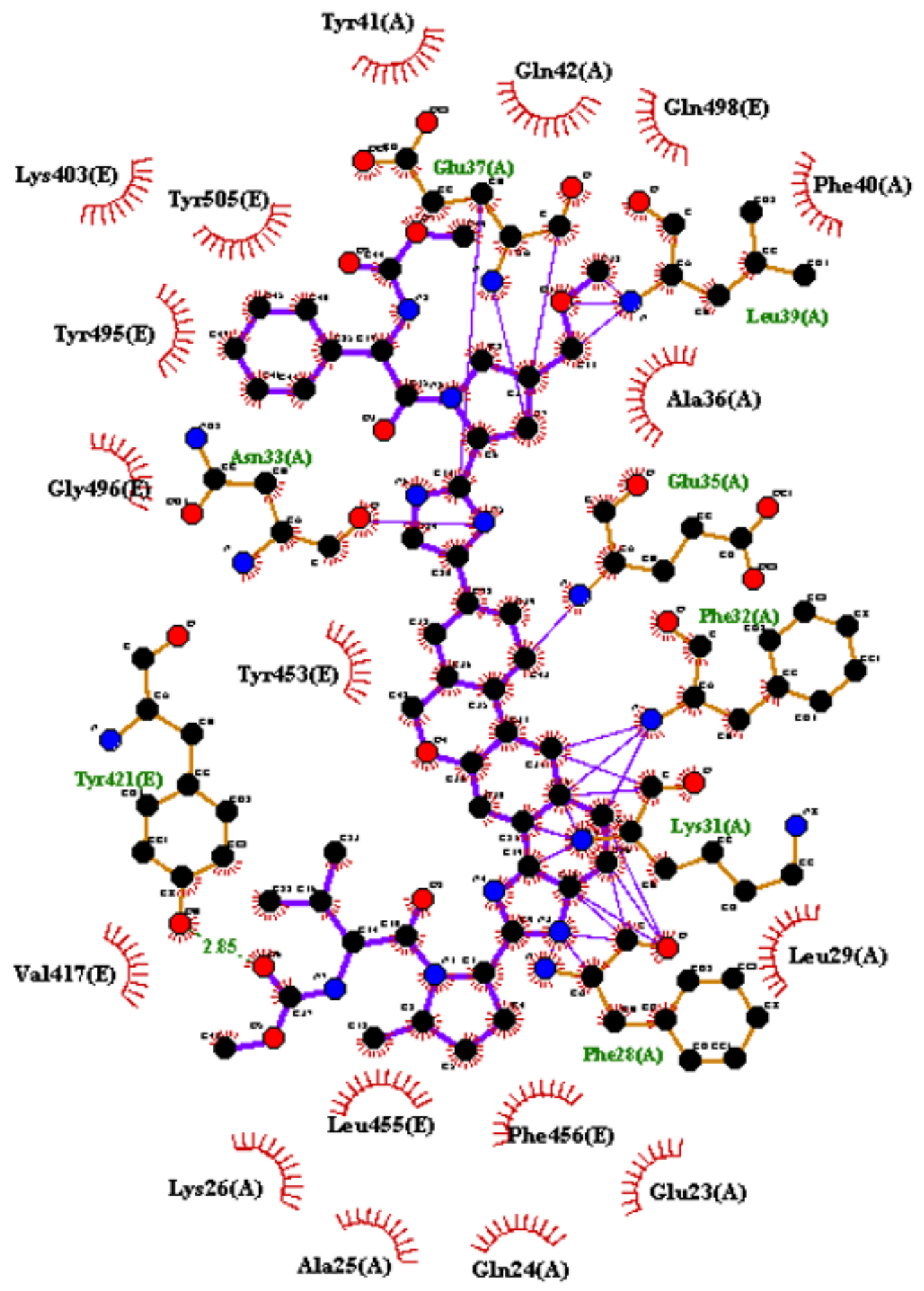

Figure 4

Two dimensional depiction of RBD/hACE2 receptor interface and Velpatasvir docked complex using LigPlot+. 


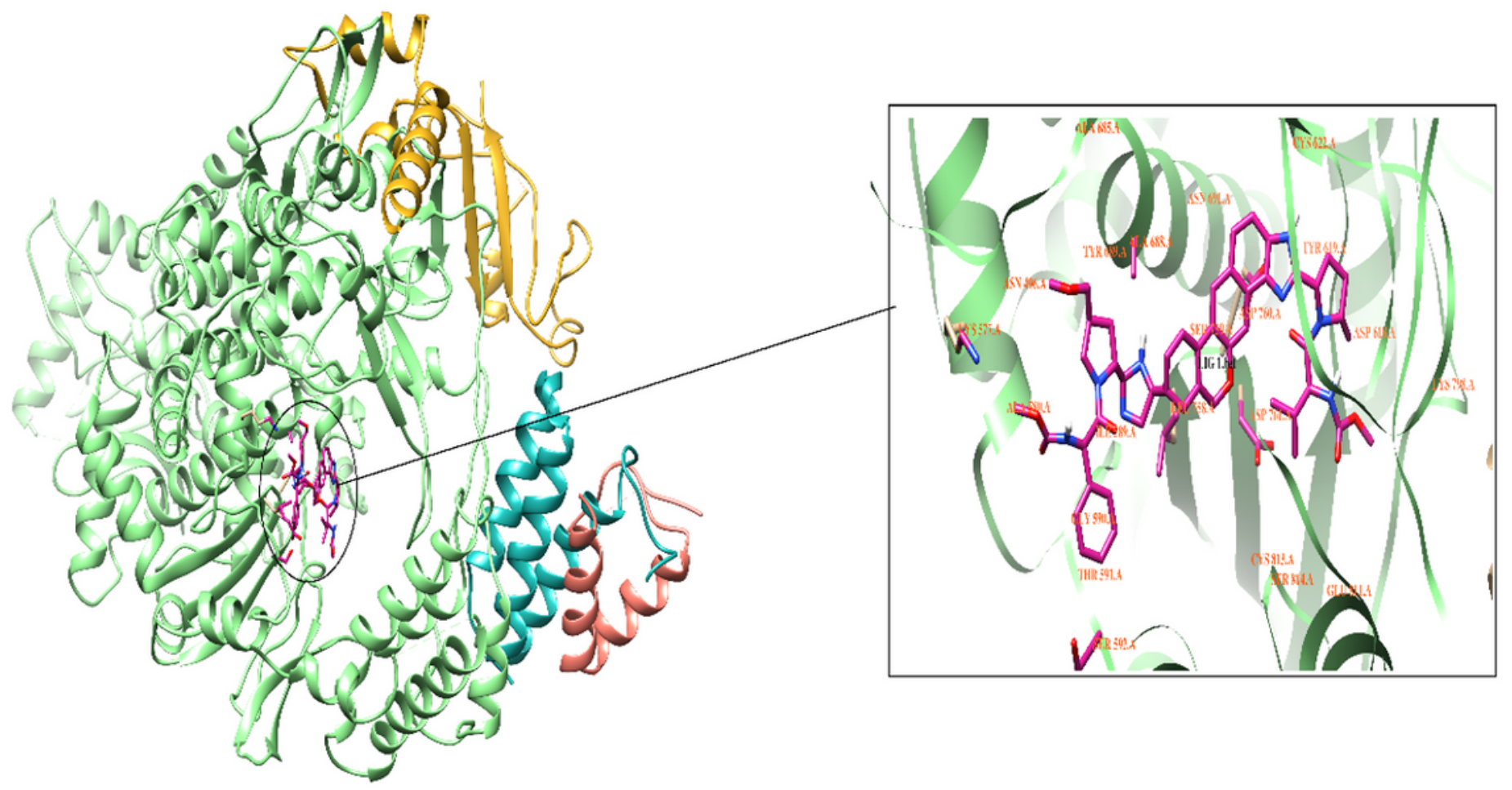

Figure 5

Docked pose: important interacting residues of 2019-CoV RdRp.

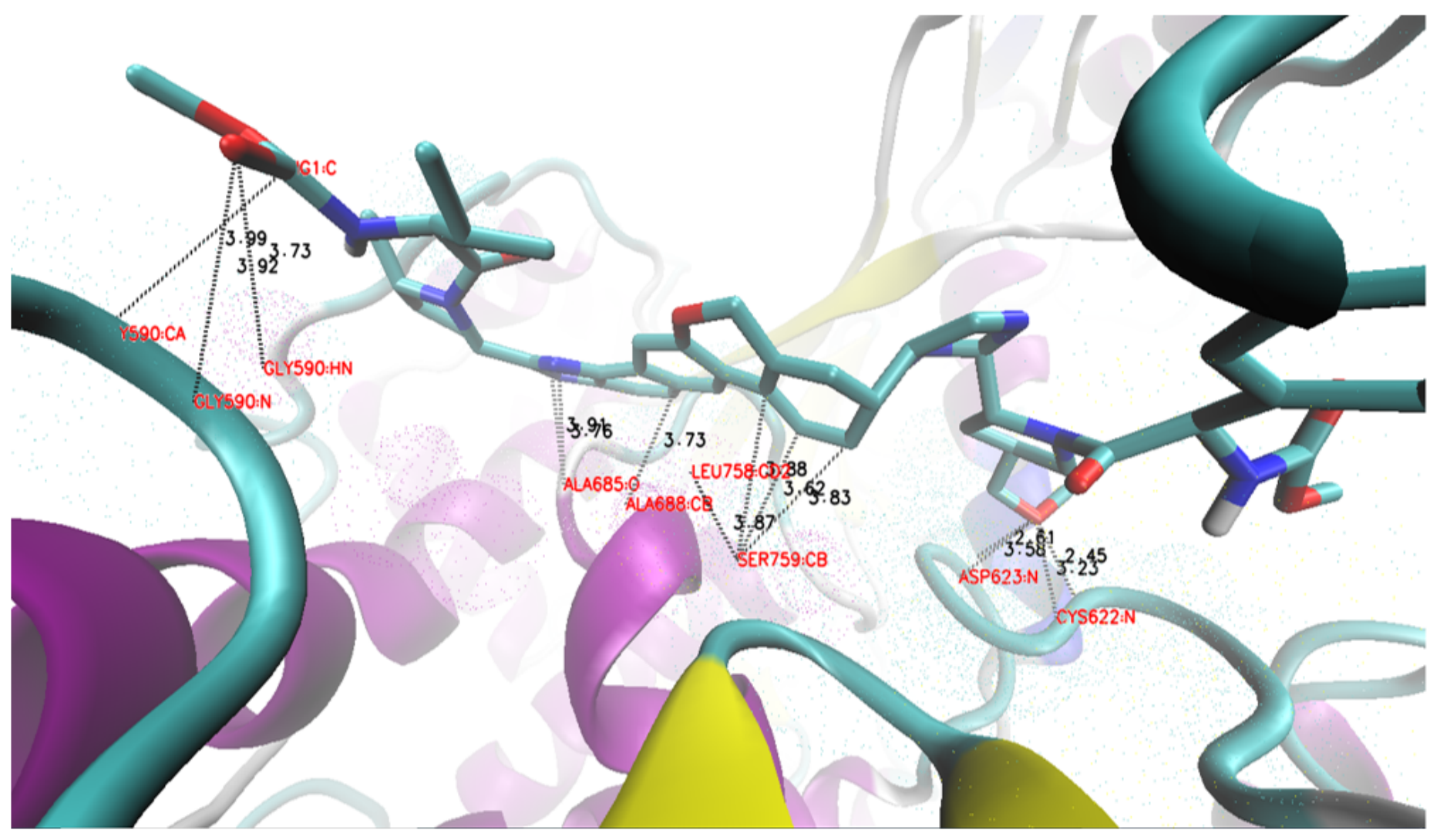

Figure 6 
Three-dimensional depiction of key interacting residues of 2019 CoV-RdRp and Velpatasvir using VMD.

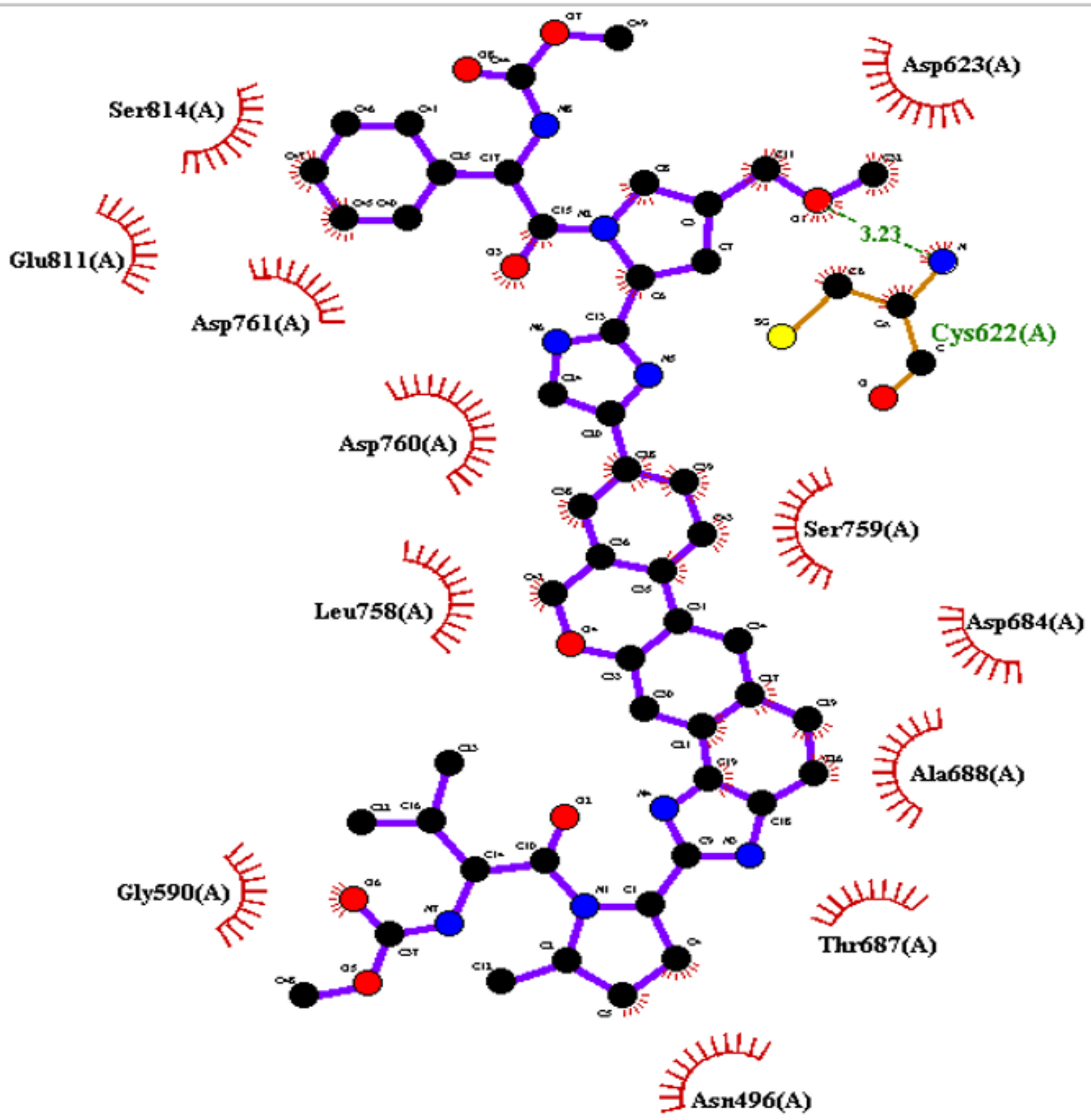

Figure 7

Two dimensional depiction of 2019-CoV RdRp docked complex using LigPlot+. 